\title{
Kuasa Wacana Keagamaan : dari Kekerasan Simbolik menuju Kekerasan Fisik
}

\author{
Ulya \\ STAIN Kudus \\ ulya.kamera@gmail.com
}

\begin{abstract}
This article aims to show the rise of violence in society. One of its causes is the power of religious discourse. The issue departs from the moslems who do their religious teaching always refer to the texts of religious discourse. While the texts that they refer, from one to others, are different.It is no problem if the texts that they refer are used as a basis to improve the quality of their religiousity in the private life. On the other hand, if it is also to judge or classify others who disagree in the public, it is very dangerous. Because it is aware or not, it will discriminate and dominate others by using the basis of religious discourse. Discrimination and domination by using religious discourse are called symbolic violence. And actually, this symbolic violence bocomes the root of emergence of physical violence
\end{abstract}

\begin{abstract}
Abstrak
Artikel ini bertujuan menunjukkan munculnya kekerasan dalam masyarakat sekarang ini, salah satunya, disebabkan dari kuasa wacana keagamaan. Persoalan ini berangkat dari masyarakat beragama yang dalam menjalankan keberagamaannya selalu merujuk pada teks-teks wacana keagamaan. Teks-teks wacana keagamaan yang mereka rujuk cenderung berbeda antara satu dengan yang lainnya. Sangat tidak menjadi persoalan jika teks yang mereka rujuk digunakan untuk meningkatkan kualitas keberagamaan di ranah individual, tetapi jika yang demikian digunakan sebagai tolok ukur untuk menilai dan mengelompokkan pihak lain yang berbeda di ranah publik, ini sangat membahayakan. Karena disadari atau tidak, hal itu akan melahirkan situasi diskriminasi dan dominasi dari satu pihak atas pihak yang lain dengan wacana keagamaan sebagai landasan pijaknya. Diskriminasi dan dominasi menggunakan wacana keagamaan akan memunculkan kekerasan simbolik. Kekerasan simbolik inilah sebenarnya yang menjadi akar munculnya kekerasan fisik.
\end{abstract}

\section{Keywords power, religious discourse, violence}




\section{A. Pendahuluan}

Akhir-akhir ini banyak terjadi kekerasan yang mengatasnamakan agama, mulai dari sweeping warung makan atau restaurant di bulan puasa, peristiwa teror bom/bom bunuh diri, pemberangusan rumah ibadah, pengusiran warga Ahmadiyah dan kelompok-kelompok Islam sempalan lainnya, dan seterusnya. Biasanya para pelaku kekerasan menyertakan teks-teks wacana agama sebagai pijakan aksinya, seperti teks-teks tentang perintah dakwah, jihad agama, pemurnian syariat Islam, dan lain-lain.

Peradaban masyarakat muslim memang peradaban teks. Hal ini telah ditunjukkan dalam kehidupan mereka di dunia dari segala sisinya yang bersumber pada teks, baik dalam beribadah kepada Allah, berpolitik, bersosial, dan seterusnya. Sebagai teks primernya adalah Alqur'an dan Hadis, sedangkan teks sekundernya adalah teks-teks wacana agama hasil telaah para ulama otoritatif terhadap teks primer yang saat ini sering dinamai Kitab Kuning.

Realitas yang demikian bermula dilakukan oleh masyarakat muslim karena keinginan dan harapan untuk mencapai derajat kesalehan, keselamatan, dan untuk meningkatkan kualitas religiusitas. Sedangkan mayoritas dari mereka tidak merasa mampu untuk memahami teks-teks primer secara langsung, maka dalam praktiknya mereka melimpahkan kepercayaannya kepada ulama otoritatif, bisa mufassir, muhaddits, fuqohâ', mutakallim, shûfî, ustadz, dan seterusnya, lalu mereka mengikuti fatwa-fatwa yang telah tertuang dalam teks-teks wacana keagamaan yang beragam. Dalam bahasa Khaled Abou el-Fadl, saat inilah terjadi pelimpahan otoritas persuasif. ${ }^{1}$ Mereka mempercayai isi kandungan dalam teks-teks sekunder tersebut sebagai sebuah kebenaran, bahkan secara tak disadari seringkali diidentikkan dengan kebenaran Tuhan. Di saat seperti inilah terjadi tumpang tindih penempatan antara teks-teks primer dan teksteks sekunder. Teks-teks sekunder yang sesungguhnya disusun oleh ulama sebagai manusia yang melekat sifat manusiawi di dalamnya ditempatkan sama dan setara dengan teks Tuhan yang bersifat ilahi. Mereka menjadikan teks sekunder yakni teks-teks wacana keagamaan sebagai tolok ukur kebenaran dalam praktik-praktik keberagamaan, baik untuk dirinya maupun pihak lainnya.

\footnotetext{
${ }^{1}$ Otoritas persuasif menurut Khaled M. Abou el-Fadl adalah kemampuan mengarahkan keyakinan atau perilaku seseorang karena kepercayaan. Khaled M. Abou el-Fadl, Speaking in God's Name: Islamic Law, Authority, and Woman (Oxford: Oneworld, 2001), h.18.
} 
Tatkala teks-teks wacana keagamaan tersebut dijadikan sebagai tolok ukur kebenaran, termasuk dalam melihat pihak lain maka lahirlah kelompok insider - outsider, pihak yang sepaham dianggap kelompok yang benar sedangkan yang tidak sepaham dinilai salah dan menjadi kelompok liyan. Teks wacana keagamaan menjadi faktor penting untuk mendefinisikan kita dan orang lain. Di sinilah maka dalam teks wacana keagamaan melekat kekuasaan atau disebut kuasa wacana keagamaan. Dan jika nalar dakwah, nalar jihad, nalar amar maruf nahi mungkar yang berjalan di atasnya maka niscaya akan melahirkan banyak persoalan dalam hubungan dengan manusia yang lain. Terlahir darinya situasi dominasi yang membawa pada kekerasan simbolik yang rentan menumbuhkan kekerasan fisik.

Tulisan ini akan mengurai secara akademik persoalan tersebut dengan membahasnya secara bertutur-turut, yaitu: dimulai dari menelaah secara kritis tentang seputar kekuasaan; lalu tentang wacana yang dalam kenyataannya adalah instrument kekuasaan; lalu tentang bentuk-bentuk atau representasi kekuasaan dalam teks-teks wacana keagamaan; dan diakhiri dengan pembahasan wacana keagamaan, dalam kaitannya dengan praksis sosial, dominasi simbolik, kekerasan simbolik, dan kekerasan fisik.

\section{B. Telaah Kritis Kekuasaan}

Kekuasaan dalam Bahasa Inggrisnya adalah power yang artinya ability to do or act, faculty of the body or mind, strenght, force, energy of force that can be used to do work (kemampuan untuk melakukan atau bertindak, bagian dari tubuh atau pikiran, kekuatan, energy yang bisa digunakan untuk bekerja). ${ }^{2}$ Dalam pengertian sehari-hari, kekuasaan biasa dipahami sebagai kemampuan untuk mempengaruhi pihak lain menurut kehendak pemegang kekuasaan, dengan kata lain bahwa kekuasaan adalah kekuatan yang dimiliki oleh subyek tertentu untuk memaksakan kehendak kepada obyek atau sasaran yang dituju. Ada pula yang mengatakan bahwa kekuasaan adalah seseorang atau sekelompok orang atau lembaga yang menjamin ketundukan masyarakat dalam wilayah tertentu.

Diskusi tentang kekuasaan menjadi salah satu tema yang menarik di antara para filosof, di antaranya yang membahasnya adalah Foucault (1926-1984), seorang filosof posmodernisme. Dia memiliki konsep

\footnotetext{
${ }^{2}$ AS. Hornby, Oxford Advanced Learner's Dictionary Of Current English (Oxford: Oxford University Press, 1987), h. 653-654.
} 
kekuasaan yang unik nan berbeda dengan makna kekuasaan di atas. Melalui pendekatan yang sangat kritis, dia menyatakan bahwa:

Power must be understood in the first instance as the multiplicity of force relations immanent in the sphere in which they operate and which constitute their own organization; as the process which, through ceaseless struggles and confrontations, transforms, strengthens, or reverses them; as the support which these force relations find in one another, thus forming a chain or a system, or on the contrary, the disjunctions and contradictions which isolate them from one another, and lastly, as the strategies in which they take effect, whose general design or institutional crystallization is embodied in the state apparatus, in the formulation of the law, in the various social hegemonies.

(Kekuasaan harus dipahami yang pertama sebagai beragam hubungan kekuatan yang imanen dimanapun hubungan ini berada dan yang menetapkan pengaturan mereka sendiri; sebagai sebuah proses yang dilalui tanpa perebutan dan konfrontasi, mengubah, menguatkan, atau melemahkan pihak-pihak yang terlibat dalam hubungan tersebut; dalam hubungan-hubungan kekuatan tersebut saling mendukung kemudian membentuk sebuah rangkaian atau sebuah sistem, atau sebaliknya yakni berpisah dan berlawanan sehingga akan mengisolasi mereka dari yang lain; dan akhirnya sebagai strategi-strategi yang mempengaruhi, yang memiliki pola umum atau perwujudan institusional yang ditubuhkan pada aparatus negara, dalam pembentukan hukum, dalam hegemoni sosial yang beragam). ${ }^{3}$

Selanjutnya karakteristik kekuasaan khas Foucault dinyatakan dalam tesis-tesisnya, yaitu: kekuasaan bukan milik istimewa, bukan didapatkan, tidak juga dijaga oleh kelas dominan, tetapi kekuasaan adalah strategi. Karena kekuasaan adalah strategi maka kekuasaan tidak bisa dimiliki tetapi dilaksanakan; ${ }^{4}$ kekuasaan juga tidak terpusat dan terbatas pada hubungan negara dan rakyat tetapi kekuasaan itu tersebar, mengalir dalam setiap adanya hubungan dalam masyarakat sampai ke tingkat yang

\footnotetext{
${ }^{3}$ Michel Foucault, The History of Sexuality Volume I: An Introduction, trans. Robert Hurley (New York: Vintage Books, 1990), h. 92-93.

${ }^{4}$ Michel Foucault, Discipline and Punish: The Birth of the Prison, trans. Alan Sheridan (England: Penguin Books, 1977), h. 26.
} 
paling intim sekalipun, dan dia bersifat tidak terlokalisasi; ${ }^{5}$ kekuasaan tidak bersifat dominatif yang nyata tetapi bersifat kapiler; ${ }^{6}$ dan kekuasaan lebih bersifat produktif daripada represif. ${ }^{7}$

Kekuasaan sebagai strategi maka kekuasaan selalu melekat pada situasi strategi kompleks yang ada di dalam masyarakat. ${ }^{8}$ Kekuasaan sebagai strategi tidak terlaksana melalui kekerasan fisik, kekerasan intelektual, memanipulasi ideologi, saling mendominasi, dan seterusnya, melainkan terlaksana dan berada dalam setiap adanya hubungan atau relasi yang ada di masyarakat. ${ }^{9}$ Di dalam negara, di tempat kerja, dalam proses pendidikan, di rumah sakit, di penjara, dalam keluarga, sampai dalam praktik-praktik keberagamaan merupakan wilayah berlangsungnya kekuasaan. Kekuasaan muncul sebagai akibat langsung dari adanya perbedaan, pemisahan, ketidaksamaan, ketidaksetaraan, ketidakseimbangan atau distingsi (distinction) dalam bahasa Bourdieu (1930-2002). ${ }^{10}$

Beroperasinya kekuasaan versi Foucault ini dapat diketahui dari sasaran dan tujuan, teknik, mekanisme, strategi, instrumen, dan efeknya sebagai berikut :

1. Terciptanya individu-individu yang patuh (docile bodies) adalah sasaran dan tujuan kekuasaan.

2. Disiplin dan normalisasi adalah teknik kekuasaan. Jika terciptanya individu yang patuh menjadi sasaran dan tujuan kekuasaan sebagaimana di atas, untuk mencapainya memerlukan disiplin. Adapun bentuk-bentuk metode pendisiplinan bisa melalui : ${ }^{11}$

a. Seni penyebaran yakni mengelompokkan atau membagi individu-individu ke dalam ruang-ruang tertentu upaya untuk memaksimumkan kegunaan, mencegah timbulnya kejahatan, dan mengontrol sikap dan perilaku individu, seperti: para tunawisma dikumpulkan di satu tempat, penjara untuk mereka

\footnotetext{
${ }^{5}$ Ibid., h. 27.

${ }^{6}$ Michel Foucault, The History..., h. 94; William E. Deal and Timothy K. Beal, Theory for Religious Studies (New York: Routledge, 2004), h. 94.

${ }^{7}$ Michel Foucault, The History..., h.105; juga dalam Paul Rabinow (ed.), The Foucault Reader (London: Penguin Books, 1984), h. 60.

${ }^{8}$ Michel Foucault, The History..., h. 93.

${ }^{9}$ William E. Deal and Timothy K. Beal, Theory..., h.94.

${ }^{10}$ Ibid., h.62, 64.

${ }^{11}$ Penjelasan selengkapnya tentang bentuk-bentuk metode pendisiplinan, yang terdiri dari: seni penyebaran, kontrol aktivitas, mengatur kegunaan waktu, kekuatan yang tersusun, bisa dibaca dalam Michel Foucault, Discipline..., h.141-166.
} 
yang diputuskan telah melanggar hukum, rumah sakit sebagai tempat perawatan orang-orang sakit, masjid dibangun untuk menyatukan orang-orang Islam yang beribadah, dan seterusnya.

b. Kontrol aktivitas yang dicapai melalui pengaturan waktu dengan bentuk umumnya adalah diterapkannya jadwal kegiatan. Jadwal berguna untuk membentuk keteraturan, menguasai kesibukan, dan mengatur aktivitas individu-individu dalam suatu lingkaran pengulangan.

c. Mengatur kegunaan waktu, yang dapat dicapai melalui 4 (empat) cara, yakni: membedakan antara waktu latihan dengan waktu praktik; memberi dasar-dasar sikap tubuh yang sederhana; membedakan waktu latihan dengan waktu pengujian; memberikan latihan yang tepat bagi individu sesuai dengan tingkat kemampuannya, senioritasnya, dan rangkingnya.

d. Kekuatan tersusun, yakni membentuk tubuh sebagai mesin multi segmentasi dengan cara individu yang sudah dilatih bagianbagiannya untuk suatu aktivitas tertentu pada gilirannya menjadi elemen dari satuan yang lebih besar; menyesuaikan waktu masing-masing individu agar menjadi kegiatan yang seragam dan kekuatan menjadi maksimum; dan membuat sistem perintah yang tepat, singkat, dan jelas untuk aktivitas-aktivitas tertentu.

Berdasarkan penjelasan di atas, maka secara singkat dapat dinyatakan bahwa disiplin akan menciptakan tubuh dengan 4 (empat) tipe individualitas, yaitu: seluler (melalui peran pembagian ruang), organis (melalui pengkodean aktivitas), genetis (melalui pengakumulasian waktu), dan kombinatoris (melalui penyusunan kekuatan). ${ }^{12}$

Jika terdapat tubuh yang tidak patuh, disiplin memberlakukan hukuman. Hukuman dalam disiplin dinamakan normalisasi. ${ }^{13}$ Normalisasi adalah macam hukuman sebagaimana dijalankan di dunia kemiliteran yang berfungsi untuk promosi dan differensiasi. Hanya tentara yang memiliki kemampuan yang sama akan ditempatkan dalam tingkat yang sama. Mereka yang tidak mampu akan ditempatkan pada kelompok lain untuk dilatih sampai akhirnya berkemampuan sama dengan yang lainnya. Di sinilah maka hukuman dalam disiplin bersifat mengoreksi, juga melatih. ${ }^{14}$

${ }^{12}$ Ibid., h.167.

${ }^{13}$ Baca selengkapnya dalam Ibid., h.177-184.

${ }^{14}$ Ibid., h.178-180. 
3. Panoptisisme merupakan mekanisme kekuasaan

Pelaksanaan disiplin semakin efektif, menurut Foucault, jika implementasinya mengacu pada gagasan di balik model penjara berarsitektur panoptikon sebagaimana didesain oleh Jeremy Bentham (1748-1832). Penjara berarsitektur panoptikon adalah model penjara berbangunan besar, berbentuk melingkar, dan memiliki banyak kamar di sepanjang tepi lingkarannya, sedangkan di tengah-tengahnya terdapat menara pengawas. Setiap kamar yang terdapat di sepanjang lingkaran tepi bangunan memiliki 2 (dua) jendela, yang satu menghadap ke pusat menara yang memungkinkan adanya pemantauan langsung dari menara, sedangkan yang satunya lagi berfungsi sebagai penerus cahaya dari sel yang satu ke sel yang lain. Bangunan ini menempatkan pengawas di menara pusat dan menempatkan orangorang yang diawasi pada sel-sel di sepanjang keliling bangunan. Melalui model penjara ini, pengawas dapat secara terus-menerus memantau para penghuni sel tanpa pernah dapat dilihat oleh mereka. Para penghuni sel senantiasa dipantau tanpa pernah mengetahui siapa dan berapa orang yang memantaunya. Mereka hanya mengetahui bahwa diri mereka selalu berada dalam pengawasan. Mereka menjadi obyek informasi dan tidak pernah menjadi subyek komunikasi. Mereka tidak bisa berkomunikasi satu sama yang lain. Mereka hanya dapat berkomunikasi dengan pengawas. Dengan demikian segala bentuk penyelewengan dan kekacauan yang mungkin timbul di antara individu-individu dapat diminimalisir, bahkan dicegah. ${ }^{15}$ Efek lain yang justru sangat penting dari model penjara panoptikon ini maka pengawasan atas seseorang tidak lagi melulu harus selalu dilakukan oleh pihak lain tetapi diri seseorang bisa turut mengambil alih tanggung jawab untuk melakukan pengawasan atas dirinya sendiri. ${ }^{16}$ Istilah lain adalah pengawasan yang bersifat swa-kendali, dalam arti bahwa begitu tubuh dan pikiran disentuh oleh wacana dan norma maka tubuh dengan sendirinya akan melaksanakan apa yang telah didiktekan. ${ }^{17}$

\footnotetext{
${ }^{15}$ Ibid.,h.200-201.

${ }^{16}$ Ibid., h.202.

${ }^{17}$ Mekanisme seperti ini disebut dengan biopower, yakni sebuah mekanisme untuk mengontrol dan memanipulasi tubuh melalui seperangkat prosedur baru yakni menggabungkan antara pengetahuan - kekuasaan, yang olehnya disebut dengan teknologi disiplin. Yang demikian bisa dilakukan dengan berbagai macam cara, yakni: melalui pengulangan dan pelatihan, melalui standarisasi perilaku, dan melalui kontrol tempat.
} 
Melalui model panoptikon ini maka dalam upaya menjadikan individu yang berdisiplin tidaklah memerlukan paksaan fisik, pengurungan, bahkan penyiksaan. Yang dibutuhkan adalah efeknya, yaitu kesadaran selalu diawasi meski pengawasan dilakukan secara tidak tampak (invisible) dan tidak secara terus-menerus (discontinue). Sebagai contoh terdapat teks wacana keagamaan yang disusun oleh ulama tertentu yang mewajibkan masyarakat muslim memilih pemimpin atau penguasa yang seagama. Meskipun ulama penyusunnya tidak mengawasi mereka secara langsung, mereka berpegang pada teks fatwa tersebut, mereka melaksanakannya dalam praktik kehidupan politiknya, mereka mengendalikan diri mereka sendiri untuk tidak melanggarnya. Bagi mereka teks itu sebuah kebenaran agama sehingga jika melanggarnya maka mereka akan merasa berdosa.

4. Produktivitas buah strategi kekuasaan

Kekuasaan yang dipahami sebagai strategi tidaklah bersifat negatif dan represif, sebaliknya bersifat positif dan produktif. $^{18}$ Istilah Bertens bahwa kekuasaan tidak menghancurkan tetapi menghasilkan. Kekuasaan menghasilkan realitas, memproduksi lingkup obyek dan ritus-ritus kebenaran. ${ }^{19}$ Foucault menyatakan bahwa "It traverses and produces things, it induces pleasure, forms knowledge, produces discourse" (dia memproduksi benda-benda, menginduksi kesenangan, membentuk pengetahuan, dan memproduksi wacana). ${ }^{20}$ Realitas yang muncul pertama kali sebagai produk kekuasaan adalah lahirnya individu-individu yang produktif, terampil, dan berguna. Masyarakat muslim yang patuh menjalankan perintah agama adalah contoh realitas sebagai efek produktif dari kekuasaan. Kekuasaan juga

\footnotetext{
Paul Rabinow (ed.), The Foucault..., h.17; selanjutnya dalam The History of Sexuality disebutkan bahwa biopower ini mengambil 2 (dua) bentuk, yaitu: 1). Disiplin tubuh, yang mana tubuh manusia diperlakukan seperti mesin : produktif, ekonomis, berguna. Bentuk ini muncul dalam keluarga, dunia ketentaraan/barak militer, dunia pendidikan/sekolah, dunia kedokteran/rumah sakit, dan lain-lain; 2). Aturan-aturan kependudukan yang memfokuskan pada persoalan reproduksi manusia. Bentuk ini dapat dilihat dalam praktikpraktik politik, problem kependudukan, kesehatan publik, migrasi, dan lain-lain. Michel Foucault, The History..., h.140-141.

${ }^{18}$ Paul Rabinow (ed.), The Foucault..., h. 60.

${ }^{19}$ K. Bertens, Filsafat Barat Kontemporer: Prancis (Jakarta: Gramedia Pustaka Utama, 2001), h. 322.

${ }^{20}$ Michel Foucault, The History..., h.105; Paul Rabinow (ed.), The Foucault..., h. 61.
} 
memproduksi wacana. Kekuasaan melalui kehendak untuk mengetahui akan menghasilkan wacana. Selanjutnya melalui wacana maka kehendak untuk mengetahui terumus dalam pengetahuan. Sesungguhnya antara kekuasaan dan pengetahuan terdapat relasi yang saling memperkembangkan. Tidak ada kekuasaan tanpa pengetahuan, juga tidak ada pengetahuan yang tidak mengandaikan adanya kekuasaan pada waktu yang bersamaan. ${ }^{21}$ Contoh: dalam tradisi Islam, seorang ulama otoritatif menyampaikan gagasannya atau kadang-kadang sebaliknya, masyarakat beragama mendatanginya untuk meminta fatwa tentang sebuah persoalan, lalu ulama tersebut memberikan fatwanya. Masyarakat muslim akan menganggap bahwa apa yang telah difatwakan oleh ulama tersebut adalah sebuah ajaran yang benar, yang dikehendaki Tuhan, dan ilmiah sehingga mereka mengikutinya. Di ketika ulama memberikan fatwanya lalu masyarakat muslim mengikutinya maka juga berarti melalui fatwa, ulama atau agamawan telah menghegemoni pemikiran dan mengarahkan perilaku masyarakat beragama, di situlah terdapat hubungan kekuasaan dan wacana-pengetahuan. Itu artinya bahwa untuk menguasai pihak lain dibutuhkan wacana-pengetahuan atau sebaliknya bahwa dengan pengetahuan maka seseorang akan menguasai pihak lain. Di sini jelaslah bahwa wacana menjadi instrumen kekuasaan sebagaimana penjelasan di bawah.

\section{Wacana Sebagai Instrumen Kekuasaan}

Telah disampaikan dalam penjelasan di atas bahwa wacana, termasuk wacana keagamaan, menjadi faktor penting untuk menguasai orang lain, baik dalam bentuk mendominasi, mendiskriminasi, memarjinalisasi orang lain.

Selanjutnya tentang term wacana berasal dari Bahasa Latin, discursus, lalu disebut dalam Bahasa Inggris, discourse, yang artinya speech, lecture, sermon, treatise (perkataan, kuliah, khotbah, perjanjian). ${ }^{22}$ Dalam Bahasa Indonesia dikenal dengan diskursus atau wacana yang diartikan dengan ucapan, percakapan, kuliah. ${ }^{23}$ Foucault dalam karyanya, Archaeology of Knowledge memperkenalkan pengertian wacana yang

\footnotetext{
${ }^{21}$ Michel Foucault, Discipline ..., h. 27.

${ }^{22}$ AS. Hornby, Oxford..., h. 245.

${ }^{23}$ WJS. Purwadarminta, Kamus Umum Bahasa Indonesia (Jakarta: Balai Pustaka, 1995), h. 1144.
} 
paling umum sebagai sekelompok pagelaran atau tampilan-tampilan verbal (a group of verbal performances). ${ }^{24}$

Wacana dalam pengertian di atas pasti merujuk kepada pemakaian bahasa, tetapi tidak semua pemakaian bahasa adalah wacana. Wacana tidak merujuk pada setiap bahasa yang digunakan dalam aktivitas komunikasi, tidak sekedar merujuk kepada aktus perbincangan sehari-hari (everyday speech act), namun wacana merujuk pada aktus perbincangan yang serius (serious speech act), meminjam istilah Dreyfus dan Rabinow. ${ }^{25}$ Adapun yang dimaksud dengan aktus perbincangan yang serius (serious speech act) adalah sebuah pernyataan yang berasal dari perbincangan sehari-hari (everyday speech act), tetapi ditetapkan lewat suatu prosedur validasi yang niscaya atau ditetapkan oleh suatu komunitas ahli yang memiliki otoritas, dan sebagainya, misalnya: "Semua warung makan dan restaurant harus tutup pada saat Ramadhan untuk menghormati pelaksanaan ibadah agama lain", pernyataan ini merupakan suatu everyday speech act yang menggambarkan suatu pengalaman sehari-hari yang dialami bersama dan ini tidak akan mempengaruhi buka atau tutupnya warung makan dan restaurant pada bulan Ramadhan, namun jika pernyataan tersebut dilontarkan oleh Kementerian Agama RI maka pernyataan tersebut berubah menjadi serious speech act karena bisa berakibat pada ditutupnya warung makan dan restaurant di saat Bulan Ramadhan datang. Hal ini karena Kementerian Agama sebagai institusi pemerintahan yang memiliki wewenang atau otoritas untuk mengurusi hal itu.

Sedangkan wacana secara spesifik menurut Foucault adalah sebagai sesuatu yang diproduksi (barangkali semua yang diproduksi) oleh kelompok tanda. Juga sebagai ketetapan formulasi, rangkaian kalimat atau proposisi. Istilah lain bahwa wacana didefinisikan sebagai sekelompok pernyataan yang berkaitan erat dengan sistem formasi tunggal. ${ }^{26}$

Wacana menyebar ke seluruh rangkaian hubungan dalam kehidupan sosial, mulai dari yang formal sampai yang tidak formal, mulai

\footnotetext{
${ }^{24}$ Michel Foucault, Archaeology of Knowlegde, terj. AM. Sheridan Smith (London and New York: Routledge Classics, 2002), h.120.

${ }^{25}$ Hubert L. Dreyfus and Paul Rabinow, Beyond Structuralism and Hermeneutic (Chicago: The University of Chicago Press, 1982), h.48; Rudy Harisyah Alam, Perspektif Pasca-Modernisme dalam Kajian Keagamaan dalam Tradisi Baru Penelitian Agama Islam: Tinjauan antar Disiplin Ilmu, ed. Mastuhu dan M. Deden Ridwan (Jakarta: Pusjarlit dan Penerbit Nuansa, 1998), h.68.

${ }^{26}$ Michel Foucault, Archaeology..., h. 121.
} 
dari tingkat negara sampai tingkat keluarga. Wacana berada di antara presiden-rakyat, pengusaha-buruh, dokter-pasien, guru-murid, ulamamasyarakat beragama, orang-tua - anak, suami-isteri, dan seterusnya. Motivasi dan efeknya terlihat dalam bentuk yang bermacam-macam, seperti: undang-undang; norma; interrogasi; konsultasi; narasi autobiografi; ataupun surat yang direkam, ditulis, dipasang dalam dokumen-dokumen, diterbitkan, dan dikomentari oleh orang lain. ${ }^{27}$

Agama adalah sebuah entitas yang sangat berperan dalam pembentukan wacana. Melalui ajaran-ajaran yang telah disampaikan oleh para ulama, agama mengatur bagaimana masyarakat menjalani hidup dan kehidupan, ${ }^{28}$ mulai bangun tidur sampai menjelang tidur kembali; berkaitan dengan hal-hal yang penting dan fundamental sampai hal-hal yang kecil dan sederhana; melingkupi persoalan-persoalan spiritualitas, ritualitas, sampai moralitas; dari masalah sosial, ekonomi, sampai politik. Norma dan pengaturan-pengaturan yang inheren dalam apa yang diklaim sebagai ajaran agama inilah merupakan unsur utama wacana keagamaan (religious discourse). Adapun pengertian wacana keagamaan atau disebut oleh Rudi Harisyah Alam sebagai diskursus keagamaan (religious discourse) adalah:

Diskursus yang memusatkan perhatiannya terutama pada sumber atau doktrin-doktrin ajaran agama. Diskursus ini, dengan segala klaim validitasnya, berupaya memproduksi representasi kebenaran dari nilai-nilai moral dan hukum yang terkandung di dalam doktrin ajaran agama guna mempengaruhi perilaku dan pengetahuan para pemeluknya. Diskursus keagamaan tidak hanya berkembang lewat disiplin-disiplin yang dikembangkan untuk mengkaji dan menelaah ajaran agama. Dalam kasus Islam, misalnya, disiplin tafsir, kalam, fiqih, tasawuf, dan filsafat. Akan tetapi, ia juga berkembang lewat institusi-institusi keagamaan semacam majelis ulama, lembaga pastoral, dan lainnya. ${ }^{29}$

\footnotetext{
${ }^{27}$ Michel Foucault, The History..., h.63.

28 Jereme R. Carrette, Prolog kepada Pengakuan Daging dalam Agama, Seksualitas, Kebudayaan Esai, Kuliah, dan Wawancara Terpilih Foucault, ed. Jeremy R. Carrette, terj. Indi Aunullah (Yogyakarta: Jalasutra, 2011), h. 43, 50.

${ }^{29}$ Rudy Harisyah Alam, Perspektif...,h.72. Dalam halaman yang sama, Rudi membedakan istilah wacana keagamaan atau diskursus keagamaan (religious discourse) dengan wacana agama atau diskursus agama (discourse of religion). Yang dimaksud yang terakhir adalah discourse of religious discourse yang lebih menyoroti cara atau praktik pemeluk agama dalam menafsirkan, memahami, dan mengkaji nilai-nilai yang
} 
Dari pengertian di atas, sederhananya, bahwa wacana keagamaan ini sebagai produk pemahaman para ulama terhadap sumber ajaran agama atau wahyu. Dalam konteks Islam, wacana keagamaan bisa berkembang melalui berbagai disiplin sebagai hasil telaah para ulama terhadap Alqur'an dan Hadis sehingga menghasilkan pengetahuan Tafsir atau Eksegesis, pengetahuan Hadis atau Tradisi Nabi, Kalam atau Teologi, Fiqih atau Hukum Islam, Tasawuf atau Mistik Islam, dan lain-lain; juga bisa berkembang melalui institusi-institusi keagamaan, seperti: Majelis Ulama Indonesia (MUI) dan forum-forum pemberi fatwa lainnya, misalnya: forum bahts al-masâ'il dari NU atau lembaga tarjîh dari Muhammadiyah, dan lain-lain.

Wacana yang inheren di dalamnya adalah undang-undang atau norma atau pernyataan-pernyataan ilmiah atau pengetahuan keagamaan atau fatwa-fatwa dan teks-teks keagamaan, dan lain-lain, yang dihasilkan dari setiap rangkaian hubungan dalam kegiatan sosial akan mengatur cara berpikir, cara bersikap, cara berbicara, cara mendefinisikan, cara berperilaku, dan seterusnya. Di sinilah menunjukkan bahwa dalam wacana mengandung kekuasaan atau seringkali dikenal dengan kuasa wacana. Sampai penjelasan ini maka sesungguhnya pada satu sisi wacana sebagai instrumen kekuasaan tetapi pada sisi yang lain dia juga sebagai efek dari kekuasaan sebagaimana telah dijelaskan di atas. Foucault menyatakan bahwa "Discourse can be both an instrument and an effect of power" (wacana bisa menjadi instrumen dan efek kekuasaan). ${ }^{30}$

\section{Representasi Kekuasaan dalam Wacana Agama}

Dalam tilikan pemikiran kritis dinyatakan bahwa tidak ada fakta, kejadian, pernyataan yang menampilkan dirinya secara telanjang. Semua adalah konstruksi manusia. Semuanya bersifat representasional. Tandatanda yang bersifat apapun, baik berupa pernyataan, tulisan, sikap, tingkah

terkandung dalam ajaran agama. Saya tidak mempersoalkan perbedaan tersebut karena keduanya saling berkaitan dan keduanya sama-sama menjadi obyek investigasi Foucault; selanjutnya komparasikan dengan definisi yang diberikan Naṣr Hạāmid Abū Zaid yang menyatakan bahwa wacana agama adalah wacana tentang agama yang disistematisasi dan dilembagakan dalam kelompok, partai, jabatan, dogma atau ideologi. Wacana agama adalah berbagai kemungkinan interpretatif dari agama yang mengklaim berpegang pada bahasa yang 'benar' dan 'yang sebenarnya' tentang risalah dan ajaran-Nya. Nashr Hâmid Abû Zaid, Al-Qur'an, Hermeneutik, dan Kekuasaan, terj.Dede Iswadi, Jajang A. Rohmana, Ali Mursyid (Bandung: RQiS, 2003), h.18.

${ }^{30}$ Michel Foucault, The History..., h.101. 
laku, dan lain-lain hendaknya diposisikan sebagai representasi dari sesuatu yang sebenarnya ingin diungkapkan.

Upaya modern yang mula-mula dan mengagumkan yang telah mengonseptualisasi tingkah laku representasional dikaitkan dengan kekuasaan adalah Bacon. Dia menganalisa perilaku representasional yang dilakukan individu dengan membedakan 3 (tiga) hal, yaitu : 1). Kerahasiaan (secresy) adalah perilaku yang hanya bisa dilihat melalui perilaku lain yang sengaja dilakukan untuk menutup perilaku yang sesungguhnya; 2). Pekerjaan berpura-pura (dissimulation) adalah bentuk negatif atau pengungkapan yang sebaliknya. Oleh karenanya berpura-pura tidak menjadi sesuatu yang sebenarnya. Contoh: sebenarnya seseorang telah berbuat salah tetapi dia menampilkan perilakunya yang seolah-olah tidak bersalah; 3). Pekerjaan tiruan (simulation) adalah bentuk afirmasi, yaitu tindakan meniru seseorang yang tidak bersalah (impersonating) padahal dia bersalah. ${ }^{31}$

Dalam konteks membincang tentang teks-teks wacana keagamaan juga seharusnya seperti itu. Selama ini terdapat anggapan bahwa macammacam teks wacana keagamaan yang telah diikuti dan dipraktikkan oleh masyarakat muslim secara turun-temurun, dari generasi ke generasi, dari dahulu sampai sekarang dan mungkin yang akan datang, adalah sesuatu yang alamiah, ilmiah, wajar, obyektif, bebas nilai, tanpa kepentingan, dan tanpa pemihakan, tetapi optik pemikiran kritis mengklaimnya bahwa dalam wacana tersebut adalah tempat bersembunyi kekuasaan. ${ }^{32}$ Di sini teks-teks wacana keagamaaan merupakan situs penting yang meneguhkan kekuasaan.

Untuk membuka kedok kekuasaan dalam wacana atau kuasa wacana, termasuk dalam teks-teks wacana keagamaan bisa dengan cara melihat sisi-sisi yang teramati selama ini, yang mana wacana dimaksud telah mengonkretkan dirinya melalui beberapa jalan, yaitu: ${ }^{33}$

1. Wacana merupakan praktik yang terorganisir dan mengorganisir. Berbagai aturan, norma, fatwa-fatwa agama, ataupun regulasi lain sebagai wujud konkret yang melekat dalam teks- teks wacana

\footnotetext{
${ }^{31}$ Francois Bacon, Essays (London: Oxford University Press, 1937), h. 24-25.

${ }^{32}$ Michel Foucault, The History..., h.101; Michel Foucault, Archaeology ..., h. 133-134.

${ }^{33}$ Secara keseluruhan penjelasan di atas merupakan hasil baca terhadap karya Michel

Foucault, Madness and Civilization: A History of Insanity in the Age of Reason, trans. Richard Howard ( New York: Vintage Books, 1988), h.159-198, 199-220, 221-240, 241-278 tentang as doctors and patients, the great fear, as the new division, dan birth of the asylum.
} 
keagamaan. Dia muncul dari praktik sosial yang terorganisir dari hubungan yang tidak seimbang antara 2 (dua) pihak yang ada di segenap lapisan masyarakat, yakni antara ulama dan masyarakat muslim awam, yang pada dasarnya akan mengatur hubungan keduanya. Sebagai contoh berkenaan dengan adanya sekelompok masyarakat muslim yang meminta fatwa kepada ulama tentang hukum mengucapkan selamat hari raya atau ikut merayakan hari raya umat beragama lain maka fatwa yang dikeluarkan akan mengikat dan mendisiplinkan perilaku masyarakat muslim tersebut, juga ulama pemberi fatwa. Kemudian fatwa-fatwa tersebut, bagaimanapun, berimplikasi pada marjinalisasi fatwa dan pengikut fatwa atau wacana lain yang berbeda atau berlawanan.

2. Wacana menampilkan dirinya sebagai pemilik otonomi klaim kebenaran. Sesungguhnya berbagai aturan, norma, bahkan fatwafatwa keagamaan sebagai wujud konkret dari teks-teks wacana keagamaan akan menghasilkan kebenaran tertentu. Kebenaran seperti ini tidak berada di luar kekuasaan, tetapi dia berada di dalam dan inheren dengan kekuasaan. ${ }^{34}$ Aturan, norma, bahkan fatwa-fatwa keagamaan tersebut mendaku bahwa dirinya telah memenuhi standar obyektivitas dan keilmiahan sehingga syah menjadi ukuran kebenaran. Aturan, norma, dan fatwa keagamaan seperti ini pada gilirannya akan segera dengan mudah membentuk dan mengendalikan pikiran, sikap, dan perilaku masyarakat muslim. Di sinilah maka komunitas tertentu, baik ilmuwan, ulama atau agamawan, bahkan semua lapisan masyarakat, selalu berusaha mengatur wacana mereka agar sesuai dengan tuntutan dan kaidah keilmiahan.

3. Wacana menghasilkan bidang riil dan mengubah konstelasi sosial. Berbagai aturan, norma, bahkan fatwa-fatwa keagamaan sebagai wujud konkret dari teks-teks wacana keagamaan membentuk dan mengendalikan pikiran, sikap, dan perilaku individu dan masyarakat. Dengannya juga akan mendefinisikan, memetakan, mengidentifikasi masyarakat dalam klasifikasi-klasifikasi tertentu, seperti: sakit-sehat, gila-waras, bodoh-pintar, saleh-berdosa, taat-durhaka, dan lain-lain. Terletak pada kemampuan mendefinisikan ini maka teks wacana

\footnotetext{
${ }^{34}$ Foucault menyatakan bahwa sesungguhnya kebenaran tidak berada di luar kekuasaan ... tetapi kebenaran berpusat dan melekat pada wacana-wacana ilmiah atau pengetahuan itu sendiri, juga melekat pada institusi yang memproduksinya. Paul Rabinow, The Foucault..., h.72-73.
} 
keagamaan sebagai pengetahuan akan mengubah konstelasi sosial, ${ }^{35}$ menciptakan kelompok sosial baru, dan akhirnya akan melahirkan produk-produk riil dalam kehidupan masyarakat. Sebagai contoh: dalam disiplin Fiqih diajarkan bahwa orang Islam wajib melaksanakan salat 5 (lima) kali dalam sehari, maka wacana keagamaan semacam ini akan mengubah masyarakat yang asalnya satu kelompok setidaknya menjadi 2 (dua) kelompok, yaitu: muslim dan non-muslim, yang taat dan yang durhaka. Prasarana untuk salat maka diciptakan rumah ibadah atau masjid. Masjid adalah salah satu contoh produk bidang riil sebagai buah dari adanya teks wacana keagamaan yang melekat bersamanya kekuasaan.

\section{E. Wacana Keagamaan, Praksis Sosial, Dominasi Simbolik, dan Kekerasan Simbolik, Kekerasan Fisik}

Penjelasan sebelumnya telah dipaparkan bahwa jika teks-teks wacana keagamaan melalui bentuknya berupa aturan-aturan atau normanorma, dan lain-lain, akan menentukan perspektif dan mendefinisikan realitas atau obyek tertentu. Berkenaan dengan hal ini Foucault telah menyontohkan tentang munculnya teks wacana klinis. Menurutnya bahwa teks wacana klinis berupa pernyataan-pernyataan medis yang tidak bisa berasal dari siapa saja tetapi berasal dari komunitas dokter. Status seorang dokter menyangkut kriteria kompetensi dan pengetahuan; lembaga, sistem, dan norma-norma pendidikan; prasyarat hukum yang memberikannya hak untuk mempraktikkan dan memperluas pengetahuannya atas seseorang. Dokter menciptakan wacana dalam situs-situs institusionalnya, berupa: rumah sakit, laboratorium, dan lain-lain, yang darinya wacana mengambil sumber legitimasi dan titik aplikasinya. ${ }^{36}$

Demikian pula teks-teks wacana keagamaan. Teks-teks wacana keagamaan berupa pernyataan-pernyataan bermakna, aturan-aturan, norma, fatwa-fatwa keagamaan sebagai produk pemikiran para ulama. Mereka adalah orang-orang yang dianggap memiliki otoritas karena memiliki kualifikasi pengetahuan dan memenuhi kompetensi tertentu. Sebagaimana dokter, maka melalui teks wacana keagamaan yang mereka fatwakan menjadi titik pangkal dan sumber legitimasi karena dengannya akan mendefinisikan persoalan keagamaan tertentu, kemudian darinya

\footnotetext{
${ }^{35}$ Haryatmoko, Kekuasaan Melahirkan Anti Kekuasaan: Menelanjangi Mekanisme dan Teknik Kekuasaan Bersama Foucault, Basis, Nomor 01 - 02, Tahun ke-51, Januari Februari 2002, 13.

${ }^{36}$ Michel Foucault, Archaeology..., h. 56.
} 
membentuk cara berpikir, mengonstitusi sikap, dan menuntun perilaku masyarakat muslim tertentu ke arah tertentu pula.

Beberapa kasus semacam ini selalu menyertai praktik keberagamaan dalam Islam yang dilakukan oleh masyarakat muslim secara turun temurun, dari zaman dahulu kala hingga sekarang ini, sebagai akibat dari adanya peristiwa keterwakilan atau pelimpahan kepercayaan atau otoritas dari masyarakat umum ke ulama otoritatif. Fuqohā' ( ulama ahli hukum Islam) memfatwakan bahwa salat harus menghadap kiblat yaitu Kabah di Kota Makkah, jika tidak menghadap kiblat maka teks wacana keagamaan telah mengklaim salat seseorang tersebut batal dan tidak diterima oleh Tuhan; mutakallim (ulama ahli ilmu kalam atau teolog) yang ekstrim menyatakan bahwa terhadap orang kafir (non-Islam) harus diperlakukan atasnya jihad maka teks wacana ini dalam kenyataannya telah menjadi dasar tumbuhnya kekerasan yang mengatasnamakan agama; Muslim mayoritas sepakat bahwa Nabi Muhammad adalah Nabi yang paling akhir, Allah tidak mengutus nabi lagi setelah itu, Oleh karena itu jika kelompok Ahmadiyah memiliki kepercayaan tentang sosok Mirza Ghulam Ahmad sebagai sosok nabi setelah Nabi Muhammad, maka kelompok ini diklaim kelompok muslim sesat; juga moralitas Islam telah menganjurkan bahwa untuk memulai suatu yang baik hendaknya membaca Basmalah. Wacana ini telah mengatur tingkah laku masyarakat muslim sehingga mereka mendisiplinkan diri melalui latihan-latihan sejak kecil dan mempraktikkan norma kebenaran ini dalam kebiasaan seharihari. Begitulah teks-teks wacana keagamaan telah mendikte praktikpraktik keberagamaan dalam Islam dan seperti itu pula kekuasaan menyusup dalam teks-teks wacana keagamaan dalam Islam berjalan.

Sesungguhnya teks wacana keagamaan terbukti telah mengatur, baik individu maupun masyarakat muslim, mendisiplinkan mereka sehingga tercapai uniformitas dalam persoalan apapun, baik dalam persoalan hubungan horisontal yaitu antara manusia dengan manusia yang lain dalam kegiatan sosial, aktivitas perekonomian, perilaku politik, dan lain-lain, dan terlebih-lebih dalam persoalan hubungan vertikal yakni dengan Tuhan dalam aktivitas ritualitas. Uniformitas tersebut terepresentasikan dalam bentuk keseragaman atau kesamaan pendapat, sikap, perilaku, bahasa, pakaian, dan lainnya. Adanya uniformitas pendapat, sikap dan perilaku maka akan dihasilkan identitas yang sama dalam masyarakat muslim tertentu, pastinya hal semacam ini akan 
memudahkan kontrol upaya memperoleh kepatuhan. Dalam sudut pandang inilah wacana memiliki kekuatan praktis. ${ }^{37}$

Sesungguhnya tatkala teks-teks wacana keagamaan, baik dalam tataran teoritis maupun praktis, telah mengatur, mendefinisikan, mengelompokkan, mendisiplinkan pihak lain, maka di situlah teks wacana keagamaan mendominasi mereka secara tidak langsung. Di sinilah kemudian muncul istilah dominasi simbolik. Oleh Foucault bahwa adanya dominasi simbolik ini biasanya ditandai dengan adanya kondisi-kondisi yang mengobyektifikasi atau mengarahkan korban dengan menggunakan 3 (tiga) cara, yaitu: 1). Subyek mengkategorisasikannya, membagi, dan memanipulasi korbannya. Contoh: ini muslim-itu kafir, ini salah-itu benar, muslim yang saleh-muslim berdosa, NU-Muhammadiyah, dan seterusnya; 2). Subyek datang dengan alibi klaim ilmiah. Contoh: seperti ini ilmiah yang itu tidak ilmiah, ini masuk akal - itu tidak masuk akal, teks wacana keagamaan ini sesuai dengan ajaran Alqur'an - sedang teks yang itu tidak sesuai, dan lain-lain; 3). Subyek membentuk korbannya ke dalam makna - memberi pada mereka sendiri. ${ }^{38}$

Dominasi simbolik semacam ini akan melahirkan kekerasan simbolik, menggunakan istilah Bourdieu. ${ }^{39}$ Kekerasan simbolik adalah kekerasan yang tak tampak dan bersifat laten atau kekerasan yang lembut. Disebut demikian karena korban tidak merasakan jika dirinya berada dalam ruang kekerasan, korban justru menerima dan menyetujui posisinya, bahkan dia merasakan berada dalam posisi yang seharusnya dan sepantasnya. Dari dahulu kala sampai sekarang ini tatkala secara langsung, masyarakat muslim awam mengikuti fatwa-fatwa ulama, atau secara tidak langsung mematuhi teks-teks wacana keagamaan yang merupakan

\footnotetext{
${ }^{37}$ Ibid., h. 51, 54.

${ }^{38}$ Paul Rabinow (ed.), The Foucault..., h. 12.

${ }^{39}$ Istilah kekerasan simbolik ini ditemukan oleh Bourdieu melalui penelitiannya terhadap masyarakat Kabyle, khususnya tentang pemberian atau hadiah. Pada masyarakat Kabyle tidak terdapat lembaga-lembaga yang dapat dobjektivikasi dalam membenarkan relasi dominasi. Dalam masyarakat Kabyle model kekerasan yang mereka alami bukan dalam bentuk kekerasan yang tampak, akan tetapi dalam bentuk kekerasan simbolik atau kekerasan yang lembut, yang tidak diakui sebagai kekerasan, karena didasarkan atas percaya diri, loyalitas personal, kesediaan menerima, pemberian, utang budi, pengakuan, kesalehan yang semuanya diterima sebagai pernghormatan etis atu bentuk kesalehan. Dikutip dari Akhyar Yusuf Lubis, Posmodernisme Teori dan Metode (Jakarta : Raja Grafindo Persada, 2014), h. 125.
} 
susunan atau produk para ulama maka mereka memandangnya bukan sebagai korban kekerasan, justru mereka menganggapnya telah berada dalam jalan yang benar. Bagi mereka sudah seharusnya mengikuti para ulama sebagai orang yang ahli dalam menerjemahkan keinginan, kehendak, pesan-pesan Tuhan yang telah tertuang dalam Alqur'an. Dalam pada itu bahkan seringkali mereka tidak menyadarinya telah menempatkan teks-teks wacana keagamaan sususan para ulama tersebut sama dan identik dengan pesan Tuhan dalam Alqur'an. Mereka akan membela mati matian jika ada pihak atau kekuatan lain yang menyerang atau menyalahkannya.

Kekerasan simbolik seringkali tidak dianggap, tidak diakui sebagai kekerasan karena memang didasarkan atas pelimpahan kepercayaan, loyalitas personal, kesediaan menerima, pemberian, hutang budi, pengakuan, kesalehan, yang semuanya diterima karena seringkali yang terjadi justru melalui pengatasnamaan penghormatan etis atau berbentuk kesalehan. Kekerasan simbolik berjalan dengan menggunakan sarana wacana. Wacana menjadi landasan pijakannya.

Dominasi simbolik yang telah melahirkan kekerasan simbolik akibat kuasa teks-teks wacana keagamaan sebagaimana penjelasan dan contoh-contoh di atas memberikan implikasi positif, yakni cenderung bisa meningkatkan produktivitas keberagamaan masyarakat muslim. Teks-teks wacana keagamaan susunan para ulama dijadikan referensi dan rujukan justifikasi atau legitimasi dalam melaksanakan ajaran agama. Mereka menjadi lebih patuh dan disiplin. Mereka berkeyakinan, jika mereka tidak melakukannya sesuai dengan apa yang telah tertulis dalam teks-teks wacana keagamaan tersebut, mereka akan merasa bersalah atau berdosa, menganggap diri mereka tidak religious, dan akan mendapatkan hukuman kelak di hari akhir, dan seterusnya. Sebaliknya jika mereka melakukannya maka akan mendapatkan pahala, keselamatan, bertambah kesalehannya, dan akan masuk surga.

Di samping menjadi rujukan keberagamaan secara pribadi, teksteks wacana keagamaan dalam realitasnya juga tak jarang menjadi rujukan etis dalam hubungan sosial-politik. Sebagai contoh tatkala sedang ramairamainya Pemilihan Kepala Desa (Pilkades), Pemilihan Bupati (Pilbup), Pemilihan Kepala Daerah (Pilkada), bahkan Pemilihan Presiden(Pilpres), maka sebenarnya banyak isu politik yang berkedok atau mengatasnamakan agama atau wacana agama, di antaranya tentang larangan memilih pimpinan perempuan, larangan memilih pimpinan yang tak seiman atau seagama, dan lain-lain. Belum lagi persoalan sering 
munculnya teror bom atau terjadinya bom bunuh diri yang mengatasnamakan jihad agama. Juga semakin maraknya kelompokkelompok transnasional, misalnya: Hizbut Tahrir Indonesia (HTI), Ikhwanul Muslimin Indonesia (IMI), dan lain-lain, yang menghendaki formalisasi Islam di Indonesia.

Masih berkaitan dengan contoh di atas, sesungguhnya biasanya para pelaku kasus-kasus di atas selalu menyertakan, membawa-bawa teksteks wacana keagamaan. ${ }^{40}$ Selanjutnya mereka melakukan penilaian terhadap pihak lain. Bagi mereka yang sependapat atau menyetujui pendapatnya dianggap in-group. Mereka adalah kelompok yang benar, yang berada dalam jalan lurus menuju Tuhan, yang religius. Sedangkan mereka yang tidak sependapat atau tidak menyetujui pendapatnya, yang melanggarnya dikelompokkan sebagai out-group. Mereka diklaim salah, sesat, berdosa. Terhadap kelompok yang terakhir ini seharusnya dibenarkan dan diluruskan, diajak kembali ke jalan kesalehan dan

\footnotetext{
${ }^{40}$ Di antara contoh yang paling nyata adalah saat terjadi Pilkada Jakarta, yang menawarkan 2 (dua) calon pasangan, yaitu: 1). Joko Widodo-Basuki Tjahaya Purnama atau Ahok yang non-muslim dan Cina, 2). pasangan Fauzi Bowo-Nachrowi Ramli yang muslim dan Betawi (2012). Saat itu Rhoma Irama, si raja dangdut, sebagai tim sukses pasangan terakhir berorasi di tengah-tengah para jamaah salat tarawih di masjid al-Isra, Tanjung Duren, Jakarta Barat, pada hari Minggu, 29 Juli 2012 . Dengan mengatasnamakan ajaran agama, dia mengimbau agar mereka memilih pemimpin yang seiman. Dia berkata: "Islam itu agama yang sempurna, memilih pemimpin bukan hanya soal politik, melainkan juga ibadah. Pilihlah yang seiman dengan masyarakat Jakarta". Lihat dalam Kompas, 30 Juli 2012. Contoh yang lain bisa dicermati kisah para tokoh peristiwa bom Bali I di tahun 2002 yang melibatkan pemeran utama, Abdul Aziz alias Imam Samudra, Ali Ghufron alias Mukhlas, dan Amrozi. Tatkala menghadapi eksekusi mati pada tanggal 8 November 2008, mereka tidak gentar apalagi gemetar. Mereka tetap tenang, tidak merasa menyesal atas perbuatan yang mengakibatkan 202 orang tak berdosa meregang nyawa dan 209 orang tak bersalah terluka. Mereka justru bangga karena apa yang dilakukannya dipersepsi oleh mereka sebagai tindakan membela Yang Ilahi, sehingga eksekusi mati dipahaminya sama dengan mati syahid (mati karena membela Islam, agama Yang Ilahi). Mereka menyertakan teks-teks agama dan perilaku nabi untuk melegalisasi perilakunya ini, seperti yang disuarakan oleh Imam Samudra bahwa "Puncak amal adalah jihad. Jihad adalah memerangi orang kafir". Pernyataan serupa disetujui oleh Amrozi yang menyatakan berjihad memerangi orang kafir atau musyrik adalah wajib bagi muslim. Imam Ghufron menguatkan pendapat kedua temannya akan urgensi jihad dengan melihat historisitas Nabi Muhammad. Dia menyatakan bahwa: "Sepuluh tahun Nabi di Madinah, haji hanya sekali; umroh, kalau tidak salah, 3 kali ; perang berapa kali? 77 kali”. Baca, "Laporan Khusus Detik-detik Eksekusi Amrozi, Dkk" dalam Kompas, tanggal 10 November 2002. Diakses tanggal 19 Agustus 2016. Juga dalam, "Trio Mujahid Imam Samudra" dalam Youtube. Diakses tanggal 19 Agustus 2016.
} 
keselamatan. Dalam istilah agama, terhadap kelompok ini hendaknya dikenakan upaya-upaya amar ma'ruf nahi mungkar.

Dalam perjalanan seperti ini maka dominasi simbolik yang telah melahirkan kekerasan simbolik akibat kuasa teks-teks wacana keagamaan menjadi rentan terhadap kekerasan yang nyata. Kekerasan yang nyata, baik hanya berupa ketegangan psikis ataupun bahkan konflik fisik, disebabkan karena sikap eksklusif tatkala memandang pihak lain yang berbeda. Baginya kebenaran itu tunggal dan ada pada dirinya.

Dalam konteks seperti di atas maka tatkala timbul persepsi yang mengatakan bahwa teks-teks wacana keagamaan, bahkan agama kerap menjadi sumber diskriminasi dan dominasi, menjadi tidaklah terelakkan. Teks-teks wacana keagamaan bukannya membantu meretas diskriminasi dan dominasi tetapi malahan memberikan landasan ideologi dan pembenaran terhadapnya.

Sebagai masyarakat beragama, yang seperti ini menjadi sebuah ironi. Penolakan disertai pembelaan terhadap persepsi tersebut di atas memang telah banyak dilakukan, tetapi biasanya hanya berhenti pada dataran yang sangat normatif, seperti yang seringkali terdengar bahwa tidak agama apapun yang mengajarkan kekerasan, agama apapun selalu mengajarkan perdamaian. Mereka yang melakukan pembelaan seperti ini justru belum menyadari akan adanya gap atau jarak antara dassein dan das sollen, yang seharusnya dan yang senyatanya, antara ajaran dengan praktiknya. Di sinilah yang seharusnya menjadi tugas masyarakat beragama untuk menjembatani jarak tersebut, agar yang seharusnya bisa terwujud dalam yang senyatanya. Agama yang sudah diterjemahkan dalam teks-teks wacana keagamaan oleh para ulama otoritatif tidak menjadi situs pembenaran kekerasan, tetapi justru penebar kedamaian.

\section{F. Kesimpulan}

Mengakhiri pembahasan artikel sederhana ini maka penulis perlu menegaskan bahwa pada realitasnya masyarakat beragama dalam menjalankan keberagamaannya selalu berpegang pada teks. Mula-mula teks yang dijadikan pegangan adalah teks primer, utamanya Alqur'an sebagai produk orisinal Allah. Namun tatkala Alqur'an ini sudah turun ke ruang dunia maka Alqur'an yang semula produk orisinal Allah berubah bentuk, beralih rupa menjadi teks-teks wacana keagamaan produk manusia, utamanya para ulama otoritatif. Teks-teks wacana keagamaan ini merupakan produk interpretasi ulama otoritatif terhadap Alqur'an. 
Meskipun ayat Alqur'annya sama, produk interpretasinya beragam.Teks yang terakhir inilah justru yang dalam kenyataannya dijadikan rujukan beragama. Ironisnya seringkali yang terjadi bahwa teks terakhir yang sejatinya produk manusia biasa yang serba terbatas kemampuannya didudukkan pada posisi yang sama dengan teks produk Tuhan Yang Serba Maha.

Berhadapan dengan persoalan tersebut barangkali tidak banyak menuai problem jika teks-teks wacana keagamaan yang beragam, hasil susunan manusia tersebut digunakan sebagai landasan religiusitas dalam hubungannya dengan Allah semata, tidak digunakan satu-satunya tolok ukur kebenaran dalam menilai, mendefinisikan, menempatkan, mengelompokkan pihak lain, tidak pula dijadikan sebagai landasan etis dalam hubungan sosial. Jika seperti ini yang terjadi maka teks-teks wacana keagamaan justu menjadi situs menguasai pihak lain, akibatnya terjadilah diskriminasi atas pihak yang tak sependapat, dominasi ataupun hegemoni dari pendapat mayoritas atas pendapat minoritas, dan seterusnya. Dominasi, hegemoni, kuasa-menguasai melalui wacana akan memunculkan kekerasan simbolik. Dari kekerasan simbolik inilah sebenarnya yang menjadi akar munculnya kekerasan dan konflik fisik yang justru mengatasnakmakan ajaran agama. Akibatnya 'kesucian' agama yang melekat dengannya teks-teks wacana keagamaan menjadi ternoda.

\section{DAFTAR PUSTAKA}

Alam, Rudy Harisyah, 1998, Perspektif Pasca-Modernisme dalam Kajian Keagamaan dalam Tradisi Baru Penelitian Agama Islam: Tinjauan antar Disiplin Ilmu, ed. Mastuhu dan M. Deden Ridwan, Jakarta: Pusjarlit dan Penerbit Nuansa.

Bacon, Francois, 1937, Essays, London: Oxford University Press.

Bertens, K., 2001, Filsafat Barat Kontemporer: Prancis, Jakarta: Gramedia Pustaka Utama.

Carrette, Jereme R., 2011, Prolog kepada Pengakuan Daging dalam Agama, Seksualitas, Kebudayaan Esai, Kuliah, dan Wawancara Terpilih Foucault, ed. Jeremy R. Carrette, terj. Indi Aunullah, Yogyakarta: Jalasutra, 2011. 
Deal, William E., Timothy K. Beal, 2004, Theory for Religious Studies, New York: Routledge.

Dreyfus, Hubert L., Paul Rabinow, 1982, Beyond Structuralism and Hermeneutic, Chicago: The University of Chicago Press.

El-Fadl, Khaled M. Abou, 2001, Speaking in God's Name: Islamic Law, Authority, and Woman, Oxford: Oneworld.

Foucault, Michel, 1977, Discipline and Punish: The Birth of the Prison, trans. Alan Sheridan, England: Penguin Books.

Foucault, Michel, 1988, Madness and Civilization: A History of Insanity in the Age of Reason, trans. Richard Howard, New York: Vintage Books.

Foucault, Michel, 1990, The History of Sexuality Volume I: An Introduction, trans. Robert Hurley, New York: Vintage Books.

Foucault, Michel, 2002, Archaeology of Knowlegde, terj. AM. Sheridan Smith, London and New York: Routledge Classics.

Haryatmoko, 2002, “Kekuasaan Melahirkan Anti Kekuasaan: Menelanjangi Mekanisme dan Teknik Kekuasaan Bersama Foucault”, Basis, Nomor 01 - 02, Tahun ke-51, Januari -Februari.

Hornby,AS., 1987, Oxford Advanced Learner's Dictionary Of Current English, Oxford: Oxford University Press.

Lubis, Akhyar Yusuf, 2014, Posmodernisme Teori dan Metode, Jakarta : Raja Grafindo Persada.

Purwadarminta, WJS., 1995, Kamus Umum Bahasa Indonesia, Jakarta: Balai Pustaka.

Rabinow, Paul, 1984, The Foucault Reader, London: Penguin Books Zaid, Nashr Hâmid Abû, 2003, Al-Qur'an, Hermeneutik, dan Kekuasaan, terj.Dede Iswadi, Jajang A. Rohmana, Ali Mursyid, Bandung: RQiS.

2). Dari sumber lain :

Kompas, 30 Juli 2012

Kompas, tanggal 10 November 2002

Youtube. Diakses tanggal 19 Agustus 2016. 